\title{
Quantitative Research in
}

\section{Psychology of Religion in Brazil}

\author{
A Pesquisa Quantitativa em Psicologia da Religião no Brasil
}

\section{Mary Rute Gomes Esperandio, Hartmut August*}

Pontifícia Universidade Católica do Paraná (PUCPR), Curitiba, Paraná, Brasil

\section{Abstract}

Although in Brazil Psychology of Religion historically has a tradition in qualitative research, in recent years it has been possible to observe a significant growth of quantitative publications. Thus, this paper aims to present an analysis of quantitative studies in Psychology of Religion in Brazil, published in Portuguese. For this, we surveyed indexed studies in the CAPES Bank of Theses and Dissertations (Coordination of Higher Education Personnel Training) and SciELO Journal Portal (Scientific Electronic Library Online), using several search terms such as "psychology and religion", "psychology

* MRGE: Doutora em Teologia, e-mail: mresperandio@gmail.com

HA: Mestre em Teologia, e-mail: hart@ausland.com.br 
and quantitative research", "religion and validation", "religion and scale", "religiosity and scale", "spirituality and scale", "spiritual/religious well-being scale", "spiritual/religious coping scale", "psychiatry and religion", "psychiatry and quantitative research", "psychology and validation" and "psychiatry and validation". We selected 70 studies for analysis. The results show that studies on "Psychology and religion" come from different areas of knowledge, raising the question of the specificity of "Psychology of Religion". The quantitative research indicates a trend of growth, especially in the use of scales. Studies indicate the need for further reflection on the role of religiosity and spirituality on health, on meaning construction and meaning in life processes, on feelings of spiritual well-being and promotion of mental health. Considering that these issues have been addressed from diverse fields, in order to strengthen Psychology of Religions a field of knowledge, we suggested the conduction of studies of qualitative and quantitative nature in the theoretical and empirical perspective of this discipline itself.

Keywords: Psychology of Religion. Quantitative studies. Research. Scales. Spirituality/ religiosity.

\section{Resumo}

Embora a Psicologia da Religião no Brasil tenha historicamente uma tradição em pesquisa qualitativa, observa-se nos últimos anos um crescimento significativo de publicações de natureza quantitativa. Assim, este texto tem como objetivo apresentar uma análise dos estudos quantitativos em Psicologia da Religião no Brasil, publicados em língua portuguesa. Para isso, procedeu-se um levantamento dos estudos indexados no Banco de Teses e Dissertações da Capes (Coordenadoria de Aperfeiçoamento de Pessoal de Nível Superior) e no Portal de Periódicos SciELO (Scientific Eletronic Library Online) usando vários descritores tais como: "psicologia e religião", "psicologia e pesquisa quantitativa", "religião e validação", "religião e escala”, "religiosidade e escala”, "espiritualidade e escala”, "escala de bem-estar religioso espiritual", "escala de coping religioso espiritual", "psiquiatria e religião", "psiquiatria e pesquisa quantitativa”, "psicologia e validação”, "psiquiatria e validação”. Foram selecionados 70 trabalhos para análise. Os resultados evidenciam que estudos em "psicologia e religião" vem de diferentes áreas de conhecimento levantando a questão sobre a especificidade do campo "psicologia da religião". As pesquisas quantitativas apontam uma tendência de crescimento, principalmente na utilização de escalas. Os estudos indicam a necessidade 
de aprofundamento na reflexão sobre o papel da religiosidade e espiritualidade na saúde, nos processos de construção de sentido e propósito na vida, nos sentimentos de bem-estar espiritual e na promoção da saúde mental. Considerando que tais temas vem sendo abordados desde campos diversos, sugere-se para fins de fortalecimento da Psicologia da Religião como área de conhecimento, a condução de estudos de natureza quali-quanti com base teórica e empírica próprias dessa disciplina.

Palavras-chave: Psicologia da Religião. Estudos quantitativos. Pesquisa. Escalas. Espiritualidade/religiosidade.

\section{Introduction}

Until 2010, the studies in Psychology of Religion in Brazil were predominantly qualitative, being most of them in a phenomenological approach, as observed by Esperandio and Marques (2014, p. 262). By analyzing the studies published between 1956 and 2005, Paiva et al. (2009) noticed that $60 \%$ of the studies showed a preference for the conceptual approach, "in light of the psychodynamic perspective" (Paiva et al., 2009, p. 445), and that only $22 \%$ of them were of empirical nature, but still predominantly qualitative (Paiva et al., 2009, p. 445). In recent years, there has been an increase in the number of quantitative studies, as we will discuss below. This study aims to present the latest data on the quantitative research in Psychology of Religion in Brazil.

As a starting point, it is important to mention that Psychology of Religion (PR) is not worried about examining the nature or existence of God. It is also not the study of psychological content present in the various religions, since this would mean a "religious Psychology", for example, Buddhist Psychology or Christian Psychology.

The focus of Psychology of Religion is on how perceptions of what the subject considers sacred impact the texture, content, direction and quality of inner life of individuals and groups. Such experiences and perceptions of what is sacred constitute an essential component of the way people organize and give meaning to their existential territory and build 
their sense of identity. People's religious/spiritual experiences affect human functioning, especially in the psychological expression, i.e. in the system of meaning construction. It is important to remember that the system of meaning construction of a subject is not something merely intra psychic or even disconnected from a broader context. The meaning construction in the individual dimension also depends on the social setting, the culture in which the subject is historically produced. To Belzen (2009), "Psychology of Religion is not entirely different from other subjects developed in the early days of Psychology; nor is it a separate sub-discipline or simply a field of application. Broadly saying, Psychology of Religion is an approach situated in the field of Psychology that attempts to describe, investigate and interpret the interrelationship between culture and the psychic functioning" (Belzen, 2009, p. 9). In this definition Belzen considers religion as part of the culture, and prioritizes a cultural Psychology of Religion. Attempts to define Psychology of Religion inevitably lead to the perception of the complexity of this task; and the rich debate that arises from this leads to the fact that no psychological theory can by itself, understand the relationship between religion and physic functioning. Therefore, there is not "one" Psychology of Religion, but distinct approaches that complement each other. To name a few, there is the Cultural Psychology of Religion, Social Psychology of Religion, Cognitive Psychology of Religion, Evolutionary Psychology of Religion, among others. Each of them offers a partial perspective on the psychological understanding of the religious phenomena and of the religious behavior. Likewise, the instruments used in the investigations in $\mathrm{PR}$ are diverse, and each of them brings specific contributions that enrich this field of knowledge.

In an analysis of the Psychology of Religion in Brazil, based on the production of periodicals and books between the years of 1956-2005, Paiva et al. (2009, p. 442) observed that qualitative studies in this field were predominant until then, although a tendency to quantitative studies was beginning to appear at the end of the 90s and the beginning of the new century.

In Brazil, studies on religious behavior under a psychological perspective can be found mainly in Psychology, Science of Religion and 
Theology Programs (Esperandio \& Marques, 2014, p. 259). However, other areas of expertise also develop these studies in their programs, such as in Health, for example. The Psychology of Religion field in Brazil is very diffuse, and researchers come from several areas, including not only psychologists, but also psychiatrists, nurses and other health professionals.

A survey conducted by Esperandio and Marques (2014) in 2013 on PR Research in the Graduate Programs in Brazil, pointed out that six out of 72 Psychology ${ }^{1}$ programs develop research in PR. Eight out of 19 Theology/Science of Religion programs (three in Theology ${ }^{2}$ and five in Science of Religion ${ }^{3}$ ) develop studies in PR. Furthermore, several researchers of the Medicine $e^{4}$ field are developing projects in that interface, in three different programs.

Given these characteristics of Psychology of Religion in Brazil, a survey of quantitative research becomes a problematic task: where to look and how to identify such quantitative research in this field?

\section{Methodology}

The strategy we used for the data collection was the choice of some search terms to find studies that could be characterized as quantitative in Psychology of Religion, regardless of the area of expertise. The search terms were "psychology and religion", "psychology and quantitative

1 Programs at following institutions: 1. University of São Paulo (USP-SP); 2. University of São Paulo (USPRibeirão); 3.Federal University of Paraná (UFPR); 4.Catholic University of Brasilia (UCB); 5.Federal University of Minas Gerais (UFMG); Pontifical Catholic University of São Paulo (PUC-SP).

2 Master's/Doctorate Programs in Theology: 1. Pontifical Catholic University of Paraná (PUCPR); 2. Pontifical Catholic University of Rio de Janeiro (PUC-Rio); 3. Higher Theological School/Ecumenical Institute for Graduate Studies (EST / IEPG).

3 Programs at following institutions: 1. Federal University of Paraíba (UFPB); 2. Catholic University of Pernambuco (UNICAP); 3.Federal University of Juiz de Fora (UFJF); 4.Pontifical Catholic University of São Paulo (PUC-SP); 5. Mackenzie University.

4 Federal University of Juiz de Fora, in the Graduate Program of Brazilian Health; at the Institute of Psychiatry, University of São Paulo and the Federal University of Rio Grande do Sul - UFRGS, at the Faculty of Medicine, in the Professional Master's Program in Health Education. 
research", "religion and validation", "religion and scale", "religiosity and scale", "spirituality and scale", "spiritual/religious well-being scale", "spiritual/religious coping scale", "psychiatry and religion”, "psychiatry and quantitative research", "psychology and validation", "psychiatry and validation", and "meaning in life and scale". We used two consultation bases: the CAPES Bank of Theses and Dissertations (Coordination of Higher Education Personnel Training) and the SciELO (Scientific Electronic Library Online).

The CAPES Bank of Theses and Dissertations is a database that stores all the works of graduate and post-graduate programs in Brazil ${ }^{5}$. SciELO is an electronic library that covers a selected collection of works, covering 344 Brazilian scientific journals indexed in its database, which makes it a great source of information. Both databases have advantages and limitations. The CAPES Bank of Theses and Dissertations is going through a process of reconstruction, as for SciELO, it includes Brazilian journals of very good quality (Superior Strata in Qualis A1, A2 and B1) that are not indexed in this search platform.

For the data collection from the CAPES Database, we searched for publications containing the search terms in their abstracts. Each study from the list of identified publications in this search was individually analyzed to assess whether it used the quantitative research as a method and whether that study was related to Psychology of Religion. We selected 25 quantitative studies, which we identified as belonging to the Psychology of Religion field (Table 1).

5 This search was carried out in September/October 2015. 
Table 1 - Selection of Theses and Dissertations in CAPES

\begin{tabular}{|c|c|c|}
\hline Search terms used & $\begin{array}{l}\text { Theses and Dissertations } \\
\text { Located }\end{array}$ & $\begin{array}{c}\text { Theses and Dissertations } \\
\text { Selected }\end{array}$ \\
\hline Psychology and religion & 34 & 3 \\
\hline $\begin{array}{l}\text { Psychology and quantitative } \\
\text { research }\end{array}$ & 1 & - \\
\hline Psychiatry and religion & 2 & - \\
\hline $\begin{array}{l}\text { Psychiatry and quantitative } \\
\text { research }\end{array}$ & - & - \\
\hline Psychology and validation & 15 & - \\
\hline Psychiatry and validation & 3 & - \\
\hline Religion and validation & 5 & 2 \\
\hline Religion and scale & 40 & 14 \\
\hline Religiosity and scale & 32 & 14 \\
\hline Spirituality and scale & - & - \\
\hline $\begin{array}{l}\text { Religious spiritual well- } \\
\text { being scale }\end{array}$ & - & - \\
\hline Religious coping scale & 5 & 5 \\
\hline Meaning in life and scale & 2 & 2 \\
\hline Sum & 139 & 40 \\
\hline Duplicate publications & & -15 \\
\hline Total & & 25 \\
\hline \multicolumn{2}{|l|}{ Total } & 25 \\
\hline
\end{tabular}

An analogous procedure was done to collect data at the SciELO Journal Portal (Table 2). After an initial search with the same terms used at the CAPES Database, all studies were individually analyzed, duplications were discarded and quantitative studies related to Psychology of Religion were selected. We found 45 quantitative studies, which added to the 25 theses and dissertations totaled 71 studies. 
Table 2 - Selection of Scientific Articles in SciELO

\begin{tabular}{|c|c|c|}
\hline Theses and Dissertations Located & Articles located & Articles Selected \\
\hline Psychology and religion & 21 & 3 \\
\hline $\begin{array}{l}\text { Psychology and quantitative } \\
\text { research }\end{array}$ & 10 & - \\
\hline Psychiatry and religion & 7 & - \\
\hline $\begin{array}{l}\text { Psychiatry and quantitative } \\
\text { research }\end{array}$ & 2 & - \\
\hline Psychology and validation & 17 & - \\
\hline Psychiatry and validation & 8 & - \\
\hline Religion and validation & 2 & 2 \\
\hline Religion and scale & 28 & 11 \\
\hline Religiosity and scale & 21 & 16 \\
\hline Spirituality and scale & 23 & 19 \\
\hline $\begin{array}{l}\text { Religious spiritual well-being } \\
\text { scale }\end{array}$ & 2 & 2 \\
\hline Religious coping scale & 10 & 8 \\
\hline Meaning in life and scale & 16 & 6 \\
\hline Sum & 167 & 67 \\
\hline Duplicate publications & & -22 \\
\hline Total & & 45 \\
\hline
\end{tabular}

From the selection of these 70 publications, we cataloged the following data of these documents in an Excel $\rightarrow$ spreadsheet: title, author(s), year of publication, subject, type of research (creation of scale, scale validation, application of scale, application of an original questionnaire), scale(s) used, database consulted and nature of the publication (doctoral thesis, master's dissertation, research paper). For the theses and dissertations, we also took note of the educational 
institution and the course in which the work was produced. For the research papers, we recorded the name of the journal in which they were published.

After tabulating the data, we loaded the spreadsheet into an intelligence software for data called QlikSense $\rightarrow$ with which we created the comparative figures used in this article.

\section{Results}

\section{Productions per year}

Paiva et al. (2009) observed that only $22 \%$ of the studies are of empirical nature. However, even "the empirical and applied studies have been predominantly of qualitative nature" (Paiva et al., 2009, p. 442). Thus, our data point to a change in the current trend. The data indicate that quantitative research in Psychology of Religion have been showing a gradual increase over time. Even though there may be issues of accuracy in the database of CAPES, it is notable that the number of articles, theses and quantitative dissertations has been increasing significantly since 2011, totaling 57 studies compared to a total of 13 studies conducted between the period of 2003 and 2010. Regarding the number of articles published, there is a similar volume in the same period: 13 articles from 2003 to 2010; and 32 articles from 2011 to mid-2015. At the same time that such evidences point to a significant trend in the increase of quantitative studies starting from 2011 on "Psychology and Religion", they raise the question of whether they may be seen as studies "of Psychology of Religion."

\section{Productions by Region and Area of Knowledge}

The theses and dissertations cataloged in this article were produced in 13 educational institutions, representing almost all regions of the country. The Northeast is represented by the universities UFPB, UFCE and UFRN. The Midwest is represented by UNB and UFGO. The Southeast 
Region is represented by USP, PUCSP, Mackenzie Presbyterian University, UFMG and Antonio Prudente Foundation. And the South Region is represented by PUCPR, PUCRS and UNISINOS.

The extent of the penetration of Psychology of Religion themes is also evidenced by the variety of master's and doctoral programs by which the dissertations and theses were defended. The programs were grouped as follows:

a) Health Sciences: Twelve studies were found distributed in the following areas: Health Sciences, Medical Sciences, Human Development and Health Processes, Nursing, Fundamental Nursing, Nursing in Adult Health, Neuroscience, Oncology, Biomedical Gerontology;

b) Psychology: A total of six studies were found in Psychology and Social Psychology;

c) Theology/Science of Religions: Seven studies were found.

The themes of Psychology of Religion permeate different areas of expertise, especially in the area of health sciences. The volume of studies in the areas of Psychology and theology/science of religions is similar.

Articles dealing with quantitative research in Psychology of Religion have been published in 24 journals of different areas. The publications were grouped according to the following areas:

- Health Sciences: Thirty studies were published in the following Journals: Science of public health, Journal of Public Health, Books of Public Health, Acta Paulista de Enfermagem, Brazilian Journal of Psychiatry, Journal of the Nursing School of the University of São Paulo, Latin American Nursing Magazine, Archives of Clinical Psychiatry (São Paulo), context text - nurse, Saúde em Debate, Journal of Psychiatry of Rio Grande do Sul, Brazilian Journal of Geriatrics and Gerontology, Brazilian Archives of Cardiology, Sao Paulo Medical Journal, Brazilian Journal of Psychiatry; 
- Psychology: 14 studies were published in the following Journals: Psicol. estud., Psic.: Teor. e Pesq., Psicol. Reflex. Crit., Psicol. Soc., Paidéia (Ribeirão Preto), Estud. psicol. (Campinas), Psicol. cienc. prof., Psicol. USP;

- Education: One study was published in the Journal Educ. e Pesquidio.

Considering that the quantitative studies are predominantly in this area, two-thirds of the articles were published in journals of Healthcare, followed by publications in areas of Psychology.

\section{Scale Use}

The studies were classified according to the type of research performed. Most studies (85\%) used already validated scales. From 2003 to 2015, we found:

- 59 quantitative studies that used validated scales;

- 6 studies with validation of new scales: Spiritual/Religious Coping Scale (Panzini \& Bandeira, 2005), WHOQOL Scale - Spirituality, Religiousness, and Personal Beliefs Module (Panzini, Maganha, Rocha, Bandeira \& Fleck, 2011); Daily Spiritual Experience Scale (Kimura, Oliveira, Mishima \& Underwood, 2011.); Duke University Religion Index - DUREL (Taunay, Gondim, Macedo, MoreiraAlmeida, Gurgel, Andrade \& Carvalho 2012a.); The Resilience Scale (Ng Deep \& Leal, 2012); Meaning in Life Questionnaire (Aquino, Veloso, Aguiar, Serafim, Pontes, Pereira \& Fernandes, 2015);

- 3 studies used own questionnaires; 


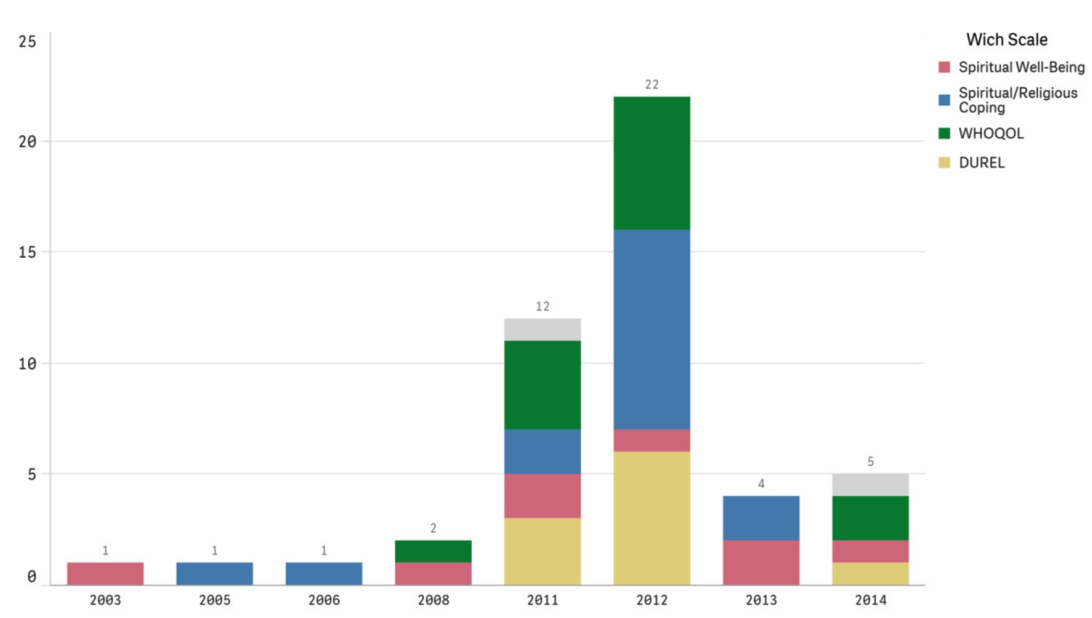

Graphic 1 - Use of Main Scales, by year

\section{Categorization of the research themes}

In the classification of the publications into thematic categories, we found studies on spirituality and health, Spiritual/Religious Coping, values, virtues and beliefs, quality of life and religiosity/spirituality, and meaning in life, in the proportions indicated in Figure 2.

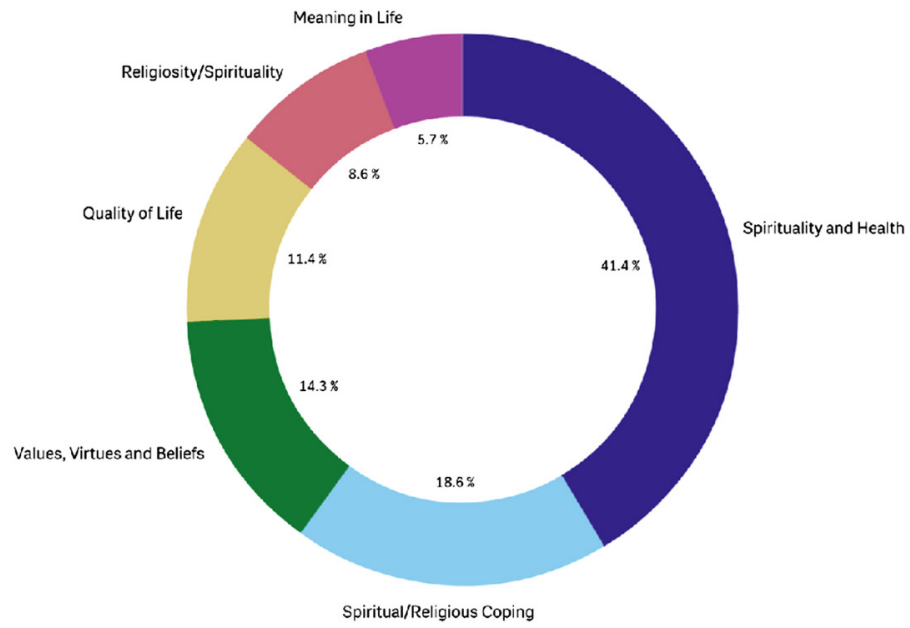

Graphic 2 - Themes of the Publications 


\section{Spirituality and Health}

The topic of spirituality and health prevails in quantitative research, making up $41.4 \%$ of the publications analyzed. The studies selected for this category include the creation of the "Intrinsic Religiosity Index" scale, and 28 applications of different scales for the evaluation of religion and spirituality of the elderly, teens, post-graduate students, patients with renal insufficiency, Psychology students, Seventh-day Adventists, psychologists, patients with epilepsy, health professionals, people following Santo Daime and Umbanda, patients with cancer, with HIV/AIDS, among others.

\section{Spiritual/Religious Coping}

Research on spiritual/religious coping represent the second largest volume of papers and reports, with $18.6 \%$ of the total. These publications deal with the validation of the Spiritual/Religious Coping Scale-SRCOPE scale (Panzini \& Bandeira, 2005), and eleven other empirical studies focused on evaluating strategies of religious coping. The research investigate Religious/Spiritual coping of the elderly, patients with cancer, people with HIV/AIDS, family members of patients in the ICU, patients with hepatitis $C$, Presbyterian women with stress, Pentecostal pastors, and people with kidney disease, among others.

\section{Values, Virtues and Beliefs}

The studies on this topic have been developed with the application of different scales such as The Resilience Scale, Children's Depression Inventory, Religious Identity, Inventory of Attitudes towards Pain, Concern for reputation, as well as two studies using their own questionnaires. Such investigations deal with values prioritized by Psychology students, smoking habits of healthcare students, workers' attitude towards pain, concern for reputation in the Northeast, teenagers with conduct 
disorder, teenagers with depression, use of alcohol and spirituality among nursing students, sexuality of young evangelicals and love among young people.

\section{Quality of life}

Publications on quality of life deal with the validation of one scale (WHOQOL Scale) and 12 applications of this and other scales in investigations aimed at correlating religion, religiosity/spirituality and quality of life for youth, adults, seniors, students of Psychology and patients after $C A B G$ surgery.

\section{Religiosity/Spirituality}

Quantitative studies with specific focus on religiosity/spirituality made use of the Religious Commitment Index - RCI, both of its creation and validation, and the validation of two other scales, the Religion Index DUREL and Daily Spiritual Experience Scale. We found three studies that used these scales to assess the spirituality of Psychology students, college students and psychiatric patients.

\section{Meaning in life}

Quantitative studies on this topic deal with the validation of the Meaning in Life Questionnaire and 3 scale applications in order to evaluate the meaning in life of adults, women with breast cancer and people with HIV/AIDS. The empirical studies of Thiago Aquino (2009, 2013 and 2015), based on the theoretical framework of Viktor Frankl, are highlighted among the studies on meaning in life and religiosity. 


\section{Discussion}

Studies show that quantitative research in Psychology of Religion in Brazil is not restricted to the area of Psychology or a single area of research. However, as observed by Paloutzian and Park (2013) in a recent reissue of the Psychology of Religion and Spirituality handbook, "the area of Psychology of Religion and Spirituality is becoming more diffuse, and research are growing not only among psychologists who think of themselves as experts in this particular field, but many psychologists, sociologists, researchers in the healthcare area, anthropologists, cognitive neuroscientists, and others" (Paloutzian \& Park, 2013, p. 661). According to the authors, such penetration of PR, including its use by other disciplines, does not mean that the distinctive character of the PR will disappear. For them, "psychologists and researchers in other disciplines have been studying religiosity and spirituality for some time, and while this multidisciplinary attention probably will continue, when focusing on the psychological aspects, such works will certainly contribute to the research corpus in Psychology of Religion and spirituality, regardless of the title or the training of the researchers who are conducting these studies" (Paloutzian \& Park, 2013, p. 661). The observations of the authors relate mainly to the North American reality. However, we see the same trend in the Brazilian context.

Data also show that the interest in quantitative research has grown especially in the area of Health Sciences, mainly in research focusing on the relationship between spirituality and health. Such interest can be related to the fact that the importance of integrating the spiritual dimension in the context of healthcare practices has been confirmed by research that present statistical data. Therefore, there are more studies using scales for data collection, explaining the growth of the variety of scales available in Portuguese, for research in Psychology of Religion and spirituality, as the recent validations of Aquino (2015), "Meaning in Life Questionnaire" and "Religious Attitudes Scale, Expanded version (RAS-20)" an updated and revised version of the previous scales created by the same author (Aquino, Gouveia, Silva \& Aguiar, 2013). As pointed out by Marques and Aguiar (2013) in a study on religiosity/ 
spirituality measurement instruments, there are currently about 19 instruments available in Portuguese.

Most of the scales used have been translated, adapted and validated for the Brazilian context, mainly: Religious/Spiritual Coping Scale, the Spiritual Well-Being Scale, Quality of Life Scale - WHOQOL, and Religion Index DUREL. Gradually there are emerging scales specially designed for the application for the Brazilian population, such as the Intrinsic Religiosity Index (Taunay et al., 2012b.); and the Religious Commitment Index - RCI (Santos et al., 2012).

\section{Final considerations}

The data collected for this study indicate the importance of research in Psychology of Religion, regardless of the area in which such studies are conducted. In the Brazilian context in which religion plays a central role in the subjectivity of a great part of the population, quantitative studies attest through strong evidence, the urgency and importance of reflection in this field of knowledge. Studies suggest the need for further reflection on the role of religiousness and spirituality on health, on construction of meaning and meaning in life processes, on spiritual well-being and promotion of mental health. If on one hand, empirical studies based on evidences have an impact due to robust statistical data, on the other hand, they leave out important data that are raised in qualitative studies.

Quantitative studies show an upward trend, especially with the use of scales for collection of data. In this sense, in order to strengthen the field of Psychology of Religion in Brazil, we suggest quali-quantitative research to be made and original scales to be built, alongside the work of adaptation and validation of scales imported from other realities to the Brazilian context.

The limited literature review presented herein relates to databases that are available, at this time, for this type of survey. There are interesting Psychology of Religion studies published in journals that have not been indexed in SciELO. However, the selection of works in 
non-indexed journals would be problematic, given the difficulty both in establishing criteria for such selection (at the risk of a biased and partial selection), and in the technical procedures for carrying out the research. Furthermore, there is also the fact that Brazil's largest database (CAPES Bank of Theses and Dissertations) has been going through a restructuring process for a long period until the present date. This database contains all the academic papers produced in post-graduate programs in the country. However, despite the limitations pointed out, the data allow us to see the current trends of research in Psychology of Religion in Brazil, in terms of methodology, research topics, areas from which these research come, but also leave no doubt about the growing academic interest in this field of knowledge.

The highest number of quantitative studies isfocused on spirituality and health. However, comparing to the international literature, research on this subject has just started, but it is emerging as one of the greatest potential topic to foster the studies on psychology of religion in Brazil.

\section{References}

AQUINO, T. A. A. de; et al. Questionário de Sentido de Vida: Evidências de sua Validade Fatorial e Consistência Interna. Psicol. cienc. prof., Brasília, v. 35, n. 1, Mar. 2015. p. 4-19.

AQUINO, T. A. A. de; GOUVEIA, V. V.; SILVA, S. de S.; AGUIAR, A. A. Escala de Atitudes Religiosas, Versão Expandida (EAR-20): Evidências de Validade. Avaliação Psicológica, v. 12, p. 109-119, 2013.

AQUINO, T. A. A. et al. Atitude religiosa e sentido da vida: um estudo correlacional. Psicologia: Ciência e Profissão, v. 29, p. 228-243, 2009.

CAPES. Banco de Teses. Brasília, 2014. Disponível em: <http://aviso.capes.gov.br/ bancodeteses/aviso.html>. Acesso em 21/09/2015. 
ESPERANDIO, M. R. G.; MARQUES, L. F. The Psychology of Religion in Brazil. The Internatinal Journal for the Psychology of Religion, 25:4. 2014. p. 255-271.

MARQUES, L. F.; SARRIERA, J. C.; DELL'AGLIO, D. D. Adaptação e validação da Escala de Bem-estar Espiritual (EBE): Adaptation and validation of Spiritual WellBeing Scale (SWS). Aval. psicol., Porto Alegre , v. 8, n. 2, ago. p. 179-186, 2009.

MARQUES, L. F.; AGUIAR, A. P. A. Instrumentos de mensuração da religiosidade/ espiritualidade (R/E) e seus construtos. Instruments for Measuring Religiousness/ Spirituality (R/S) and its constructs. Rev. Pistis Prax., Teol. Pastor., Curitiba, v. 6, n. 1, p. 107-126, jan./abr. 2014.

KIMURA, M.; OLIVEIRA, A. L. de; MISHIMA, L. S. \& UNDERWOOD, L. G. Adaptação cultural e validação da Underwood's Daily Spiritual Experience Scale versão brasileira. Rev. esc. enferm. USP, São Paulo, v. 46, n. spe, p. 99-106, Oct. 2012.

PAIVA, G. J. de et al. Psicologia da Religião no Brasil: a produção em periódicos e livros. Psic.; Teor. e Pesq. v. 25, n. 3, p. 441-446, 2009.

PALOUTZIAN, R.; PARK, C. L. Directions for the Future of the Psychology of Religion and Spirituality. In: PALOUTZIAN, R.; PARK, C. L. Handbook of the Psychology of Religion and Spirituality. New York/London: Guilford Press, 2013, p. 650-665.

PANZINI, R. G.; et al. Validação brasileira do Instrumento de Qualidade de Vida/ espiritualidade, religião e crenças pessoais. Rev. Saúde Pública, São Paulo, v. 45, n. 1, Feb. 2011. p. 153-165.

PANZINI, R. G.; BANDEIRA, D. R. Escala de coping religioso-espiritual (Escala CRE): elaboração e validação de construto. Psicol. estud., Maringá, v. 10, n. 3, p. 507516, dec. 2005.

SANTOS, W. S. S.; et al. Índice de Compromisso Religioso (ICR): elaboração e evidências psicométricas. Psicologia: Reflexão e Crítica, v. 25, n. 3, p. 523-531, 2012.

SciELO - Scientific Electronic Library Online. São Paulo: FAPESP, 2015. Disponível em: $<$ http://search.SciELO.org/>. Acesso em: 15/09/2015. 
TAUNAY, T. C. D.; et al. Validação da versão brasileira da escala de religiosidade de Duke (DUREL). Rev. psiquiatr. clín., São Paulo, v. 39, n. 4, p. 130-135, 2012.

TAUNAY, T. C.; et al. Development and validation of the Intrinsic Religiousness Inventory (IRI). Revista de Psiquiatria Clínica, v. 34, p. 76-81, 2012 b.

Received: 03/11/16

Recebido: 11/03/2015

Approved: 02/29/17

Aprovado: 29/02/17 
